\title{
RHEUMATIC INFECTION IN CHILDHOOD
}

\author{
BY \\ EDWARD C. ROSS COUPER, M.D., F.R.F.P.S., D.P.H. \\ Deputy Medical Superintendent, Walton Hospital, Liverpool; late Deputy Medical \\ Superintendent, Alder Hey Children's Hospital, Liverpool
}

There are so many writings on the subject of rheumatic infection in childhood that it is with hesitation that another is added to the list. Yet in Alder Hey Children's Hospital, with the 950 beds available before the war and the large amount of clinical material, the possible scope of a survey seemed to justify an attempt to assess the problem as it affects a proportion of the child population of the City of Liverpool. It is not proposed to deal with the question of treatment in any detail and only a short statement will be made on this aspect.

Accommodation. Two wards of 30 beds each were set aside for the treatment of rheumatic infection and all children with this infection were admitted to these wards, which were kept as quiet as possible. Frequently the accommodation proved inadequate and many patients found their way into the general medical wards.

Routine. For the first six weeks the patient was kept flat with one pillow and no exertion was allowed. During this time the patient was fed by the nursing staff. At the end of six weeks the patient was allowed to feed himself sitting up for fifteen minutes. This period of fifteen minutes was gradually increased by fifteen minutes daily. When the patient got up he was allowed to sit for fifteen minutes in a chair, this period being increased by fifteen minutes daily, until he was up for two hours, after which the periods were increased by thirty minutes. Temperature, sleeping pulse and exercise pulse were accurately charted. On discharge the parents were requested to bring the child to the Rheumatism Clinic, which was purely an after-care clinic. From there children with badly damaged hearts were recommended to schools for physically defective children or referred to the care of the school medical officers.

Classification. In all 1796 cases, admitted during the years 1936, 1937 and 1938, were reviewed. Of these 164, 88 classified as rheumatism and 76 classified as chorea, were discarded as being too doubtful for inclusion in the series. As the patients were admitted at different stages in their illness, some in their first attack and some in the course of a subsequent attack, the basis upon which they have been classified is the condition of the child on admission to hospital. The conventional division into acute and subacute cases has not been employed as this is considered to be somewhat artificial and therefore often inaccurate. The "rheumatism" cases could be divided most conveniently into two main groups, those presenting the classical features of acute articular rheumatism, with swelling, redness, etc., of joints (A.A.Rh.) and those presenting the syndrome of vague pains, 'growing pains,' anorexia, loss of weight and lassitude (V.P.). The cases of chorea were divided into mild, moderate and severe. Thus four main groups have been used in both diseases as follows:

A. Rheumatism. Those suffering on admission from-

(1) Acute articular rheumatism without heart involvement.

(2) Acute articular rheumatism with heart involvement.

(3) Vague pains with heart involvement.

(4) Vague pains without heart involvement.

B. ChOREA. Those suffering on admission from-

(1) Moderate chorea without heart involvement.

(2) Moderate chorea with heart involvement.

(3) Mild chorea with heart involvement.

(4) Mild chorea without heart involvement.

A relatively small number of cases of chorea were labelled 'severe, i.e. they required the exhibition of sedatives for their control. To avoid the system of classification becoming too cumbersome these have been included in the "moderate ${ }^{\prime}$ groups and extracted later. The above eight groups have been further subdivided into (a) those who attended the after-care clinic; and (b) those who did not attend.

Results

TABLE 1

GENERAL ANALYSIS INTO THE GROUPS OF THE CLASSIFICATION

\begin{tabular}{|c|c|c|c|c|c|c|}
\hline \multirow[b]{2}{*}{ Group } & \multicolumn{3}{|c|}{ A. Rheumatism } & \multicolumn{3}{|c|}{ B. Chorea } \\
\hline & (a) & (b) & Total & (a) & (b) & Total \\
\hline $\begin{array}{l}1 \\
2 \\
3 \\
4\end{array}$ & $\begin{array}{r}63 \\
71 \\
233 \\
145\end{array}$ & $\begin{array}{r}54 \\
60 \\
221 \\
95\end{array}$ & $\begin{array}{l}117 \\
131 \\
454 \\
240\end{array}$ & $\begin{array}{r}139 \\
81 \\
53 \\
115\end{array}$ & $\begin{array}{r}100 \\
67 \\
35 \\
100\end{array}$ & $\begin{array}{r}239 \\
148 \\
88 \\
215\end{array}$ \\
\hline Total & 512 & 430 & 942 & 388 & 302 & 690 \\
\hline
\end{tabular}


TABLE 2

ATTENDANCES AT AFTER-CARE CLINIC AND NUMBERS REFERRED TO PHYSICALLY DEFECTIVE SCHOOLS AND SCHOOL MEDICAL OFFICERS

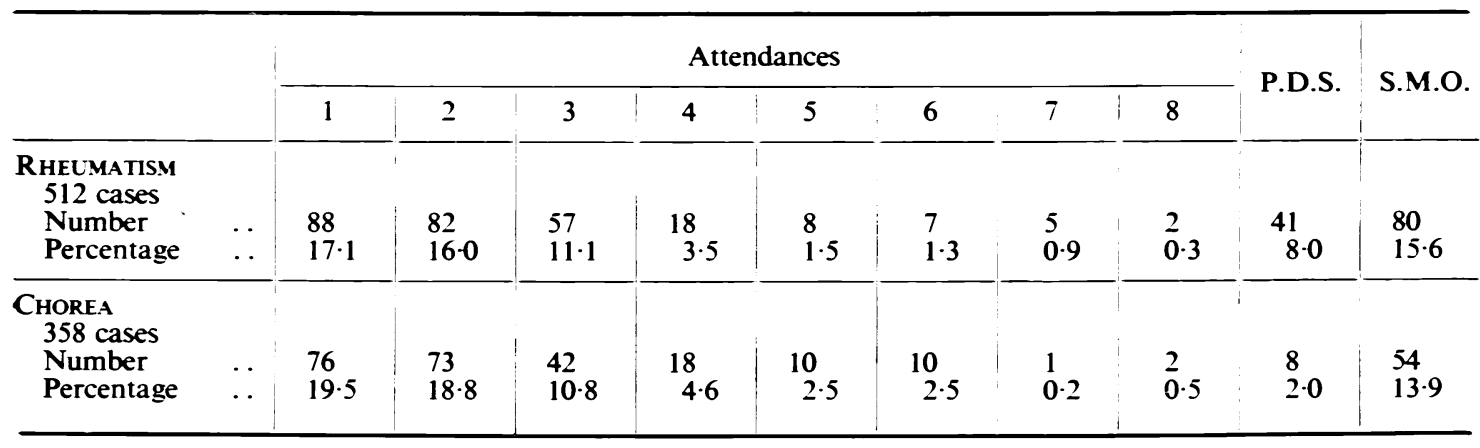

TABLE 3

SEX INCIDENCE

\begin{tabular}{|c|c|c|c|c|c|c|}
\hline & & & Male & Female & Total & Ratio of $\mathrm{M}$. to $\mathrm{F}$. \\
\hline $\begin{array}{l}\text { Rheumatism } \\
\text { Chorea .. }\end{array}$ & $\cdots$ & $\begin{array}{l}\cdots \\
\cdots\end{array}$ & $\begin{array}{l}450 \\
207\end{array}$ & $\begin{array}{l}492 \\
483\end{array}$ & $\begin{array}{l}942 \\
690\end{array}$ & $\begin{array}{l}1: 1 \cdot 09 \\
1: 2 \cdot 3\end{array}$ \\
\hline
\end{tabular}

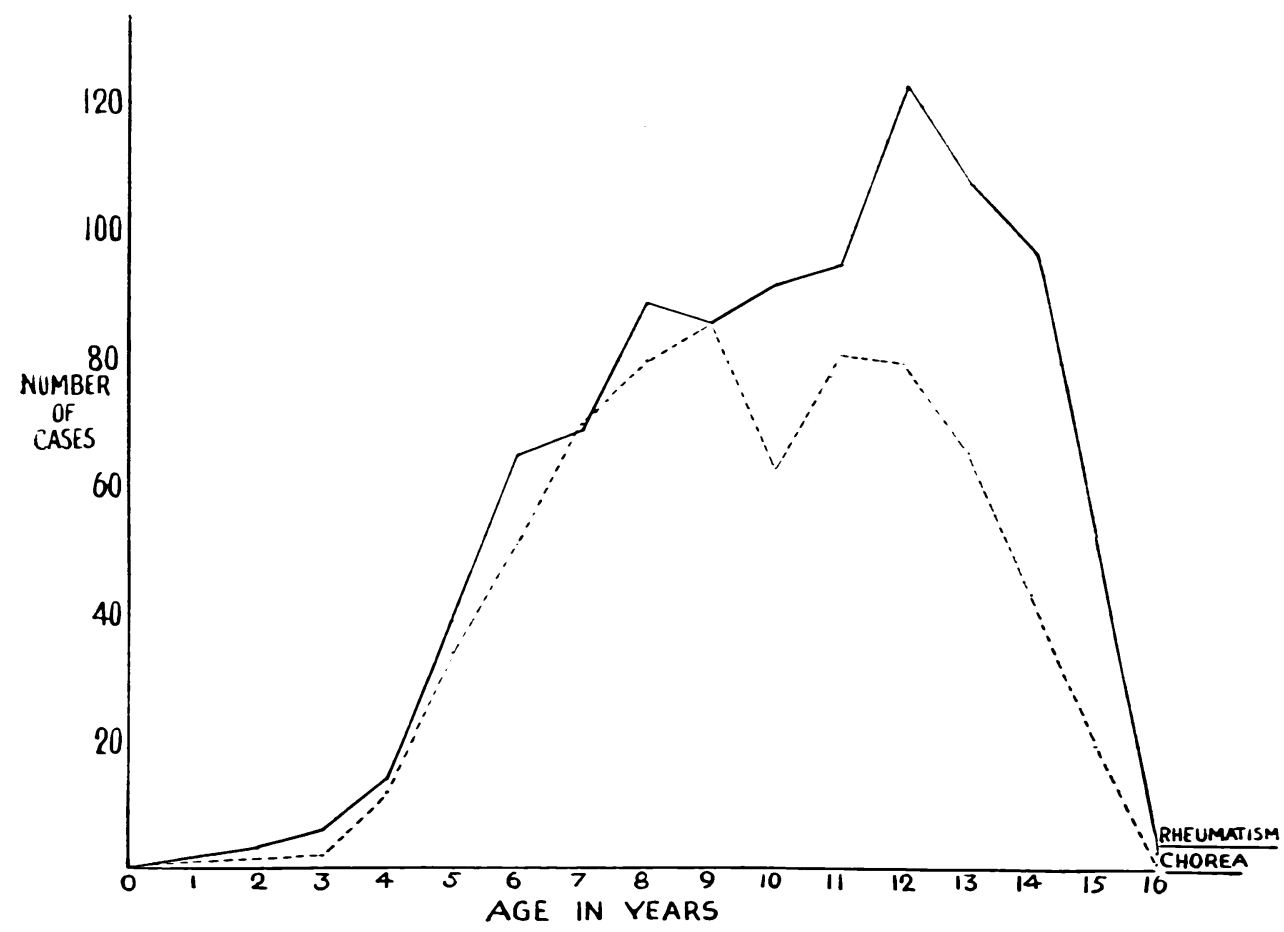

FIG. 1.-Graph indicating age distribution. 
TABLE 4

A. RHEUMATISM-ANALYSIS OF CASES ADMITTED WITHOUT HEART INVOLVEMENT

\begin{tabular}{|c|c|c|c|c|c|c|c|c|c|c|c|c|c|c|c|c|c|c|c|}
\hline \multirow[b]{2}{*}{$\begin{array}{c}\text { Group } \\
\text { A }\end{array}$} & \multirow[b]{2}{*}{$\begin{array}{c}\text { No } \\
\text { lesion }\end{array}$} & \multirow{2}{*}{$\begin{array}{l}\text { Mitral } \\
\text { systo- } \\
\text { lic } \\
\text { which } \\
\text { disap- } \\
\text { peared }\end{array}$} & \multirow{2}{*}{$\begin{array}{c}\text { Per- } \\
\text { man- } \\
\text { ent } \\
\text { mitral } \\
\text { systo- } \\
\text { lic }\end{array}$} & \multirow[b]{2}{*}{ M.R. } & \multirow{2}{*}{$\begin{array}{c}\text { M.R. } \\
\text { and } \\
\text { S. }\end{array}$} & \multirow{2}{*}{$\begin{array}{c}\text { M.R. } \\
\text { and S. } \\
\text { A.R. }\end{array}$} & \multirow{2}{*}{$\begin{array}{l}\text { M.R. } \\
\text { and S. } \\
\text { A.R. } \\
\text { and S. }\end{array}$} & \multirow{2}{*}{$\begin{array}{l}\text { M.R. } \\
\text { and } \\
\text { A.R. }\end{array}$} & \multirow[b]{2}{*}{ A.R. } & \multicolumn{3}{|c|}{ Weight } & \multirow[b]{2}{*}{$\begin{array}{c}\text { Nod- } \\
\text { ules }\end{array}$} & \multirow{2}{*}{$\begin{array}{c}\text { Ery- } \\
\text { thema } \\
\text { mar- } \\
\text { gina- } \\
\text { tum }\end{array}$} & \multirow{2}{*}{$\begin{array}{l}\text { His- } \\
\text { tory } \\
\text { of ton- } \\
\text { sillitis }\end{array}$} & \multirow{2}{*}{$\begin{array}{c}\text { No. } \\
\text { having } \\
\text { 2nd } \\
\text { attack }\end{array}$} & \multirow{2}{*}{$\begin{array}{l}\text { Lesion } \\
\text { at } \\
\text { 2nd } \\
\text { attack }\end{array}$} & \multirow[b]{2}{*}{ Death } & \multirow[b]{2}{*}{ Total } \\
\hline & & & & & & & & & & Gain & $\begin{array}{l}\text { Sta- } \\
\text { tion- } \\
\text { ary }\end{array}$ & Loss & & & & & & & \\
\hline $\begin{array}{l}\text { 1. A.A. } \\
\text { Rh. with- } \\
\text { out heart } \\
\text { lesion- } \\
\text { (a) } \ldots \\
\text { (b) } \ldots\end{array}$ & $\begin{array}{l}32 \\
24\end{array}$ & $\begin{array}{r}11 \\
8\end{array}$ & 5 & 12 & $\begin{array}{l}2 \\
1\end{array}$ & $\overline{1}$ & $\begin{array}{l}1 \\
1\end{array}$ & $\overline{2}$ & $\overline{1}$ & $\frac{26}{-}$ & 13 & 7 & $\begin{array}{l}1 \\
3\end{array}$ & $\begin{array}{l}1 \\
1\end{array}$ & $\begin{array}{l}27 \\
17\end{array}$ & $\begin{array}{r}10 \\
7\end{array}$ & $\begin{array}{l}3 \\
4\end{array}$ & $\overline{2}$ & $\begin{array}{l}63 \\
54\end{array}$ \\
\hline $\begin{array}{l}\text { 4. V.P. } \\
\text { without } \\
\text { heart } \\
\text { lesion- } \\
\text { (a) } \ldots \\
\text { (b) } \ldots\end{array}$ & $\begin{array}{l}90 \\
57\end{array}$ & $\begin{array}{l}33 \\
12\end{array}$ & $\begin{array}{l}1 \\
4\end{array}$ & $\begin{array}{l}14 \\
22\end{array}$ & $\frac{5}{-}$ & - & 1 & - & 1 & $\underline{73}$ & 20 & 24 & 3 & $\frac{2}{2}$ & $\begin{array}{l}59 \\
29\end{array}$ & $\begin{array}{r}38 \\
6\end{array}$ & $\begin{array}{l}6 \\
2\end{array}$ & $\overline{1}$ & $\begin{array}{r}145 \\
95\end{array}$ \\
\hline Totals. . & 203 & 64 & 13 & 61 & 8 & 1 & 3 & 2 & 2 & - & - & - & 7 & 6 & 132 & 61 & 15 & 3 & 357 \\
\hline
\end{tabular}

M.R. = Mitral Regurgitation. M.R. and S. = Mitral Regurgitation and Stenosis. A.R. = Aortic Regurgitation. A.R. and S. = Aortic Regurgitation and Stenosis.

TABLE 5

A. RHEUMATISM-ANALYSIS OF CASES ADMITTED WITH HEART INVOLVEMENT

A. Rheumatism

Groups 2 and 3

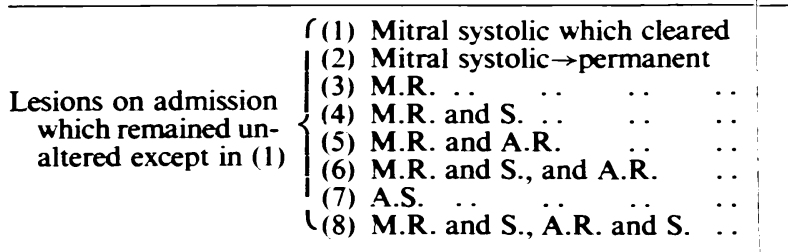
progressed while in hospital

(1) M.R. $\rightarrow$ M.S.

(2) M.R $\rightarrow$ A.R

(3) M.R $\rightarrow$ M.S. $\rightarrow$

(3) M.R. $\rightarrow$ M.S. $\rightarrow$ A.R.

(6) A.R. $\rightarrow$ A.R. and S. (W.R. negative) .
Lesions which

$\{$ (5) M.R. and S. $\rightarrow$ A.R. and S.

(7) M.R. and S. $\rightarrow$ A.R.

(8) M.R. $\rightarrow$ M.R. and S. and A.R. and S

Weight $\quad\left\{\begin{array}{llllll}\text { Gain } \ldots & \ldots & \ldots & \ldots & \ldots & \ldots \\ \text { Stationary } & \ldots & \ldots & \ldots & \ldots & \ldots \\ \text { Loss } \ldots & \ldots & \ldots & \ldots & \ldots & \ldots\end{array}\right.$

Nodules

Erythema marginatum

History of tonsillitis

Number developing lesions second attack

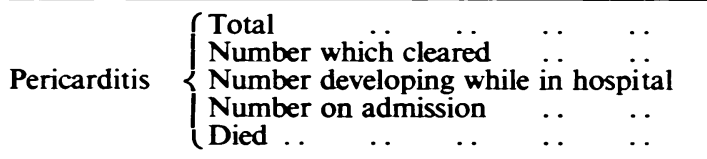

\begin{tabular}{|c|c|c|c|c|c|c|c|c|c|c|c|c|}
\hline & (Died .. & . & . & . & . & . & - & - & 3 & 21 & 24 & $4 \cdot 1$ \\
\hline Pericardial & \multicolumn{2}{|c|}{ Adhesions (old) } & .. & & . & . & 1 & 8 & - & 10 & 19 & $3 \cdot 2$ \\
\hline $\begin{array}{l}\text { Cardiac } \\
\text { failure }\end{array}$ & $\left\{\begin{array}{l}\text { Total } \\
\text { Number } \\
\text { Number } \\
\text { Died .. }\end{array}\right.$ & $\begin{array}{c}\text { velo } \\
\text { adn } \\
\ldots\end{array}$ & $\begin{array}{c}\text { g wh } \\
\text { sion } \\
\ldots\end{array}$ & $\cdots$ & $\begin{array}{c}\text { pital } \\
\ldots \\
\ldots\end{array}$ & $\begin{array}{l}\ldots \\
\ldots \\
\ldots\end{array}$ & $\begin{array}{l}- \\
-\end{array}$ & $\begin{array}{l}6 \\
1 \\
5 \\
2\end{array}$ & $\begin{array}{l}- \\
-\end{array}$ & $\begin{array}{l}35 \\
10 \\
25 \\
24\end{array}$ & $\begin{array}{l}41 \\
11 \\
30 \\
26\end{array}$ & $\begin{array}{l}7 \cdot 0 \\
1 \cdot 8 \\
5 \cdot 1 \\
4 \cdot 4\end{array}$ \\
\hline \multicolumn{2}{|c|}{ Auricular fibrillation .. } & $\ldots$ & $\ldots$ & $\ldots$ & $\ldots$ & $\ldots$ & - & 2 & - & 2 & 4 & 0.6 \\
\hline \multicolumn{2}{|c|}{ Malignant endocarditis } & . & $\ldots$ & . & . & . & - & - & 1 & 1 & 2 & 0.3 \\
\hline \multicolumn{2}{|l|}{ Total deaths } & $\ldots$ & $\ldots$ & $\ldots$ & $\ldots$ & $\ldots$ & - & 2 & 4 & 48 & 54 & $9 \cdot 2$ \\
\hline
\end{tabular}


TABLE 6

\section{B. CHOREA-ANALYSIS OF CASES ADMITTED WITHOUT HEART INVOLVEMENT}

\begin{tabular}{|c|c|c|c|c|c|c|c|c|c|c|c|c|c|c|}
\hline \multirow{2}{*}{ Group B } & \multirow{2}{*}{$\mid \begin{array}{c}\text { No } \\
\text { lesion }\end{array}$} & \multirow{2}{*}{$\begin{array}{l}\text { Mitral } \\
\text { systolic } \\
\text { which } \\
\text { disap- } \\
\text { peared }\end{array}$} & \multirow{2}{*}{$\begin{array}{c}\text { Per- } \\
\text { manent } \\
\text { mitral } \\
\text { systolic }\end{array}$} & \multirow{2}{*}{ M.R. } & \multirow{2}{*}{$\begin{array}{l}\text { M.R. } \\
\text { and } \\
\text { S. }\end{array}$} & \multirow{2}{*}{$\begin{array}{l}\text { M.R. } \\
\text { and S. } \\
\text { and } \\
\text { A.R. }\end{array}$} & \multicolumn{3}{|c|}{ Weight } & \multirow{2}{*}{$\begin{array}{c}\text { Ton- } \\
\text { silli- } \\
\text { tis }\end{array}$} & \multicolumn{2}{|c|}{$\begin{array}{c}\text { Number } \\
\text { having pre- } \\
\text { vious attacks }\end{array}$} & \multirow{2}{*}{$\begin{array}{l}\text { Lesion } \\
\text { at 2nd } \\
\text { attack }\end{array}$} & \multirow[t]{2}{*}{ Total } \\
\hline & & & & & & & Gain & $\begin{array}{c}\text { Sta- } \\
\text { tion- } \\
\text { ary }\end{array}$ & Loss & & Ch. & Rh. & & \\
\hline $\begin{array}{l}\text { 1. Ch. (a) } \\
\text { Moderate } \\
\text { Severe } \quad \text {.. }\end{array}$ & $\begin{array}{l}75 \\
16 \\
\end{array}$ & $\begin{array}{r}21 \\
6 \\
\end{array}$ & $\begin{array}{l}2 \\
1 \\
\end{array}$ & $\begin{array}{r}16 \\
1 \\
\end{array}$ & - & - & $\begin{array}{l}57 \\
15 \\
\end{array}$ & $\begin{array}{r}11 \\
0 \\
\end{array}$ & $\begin{array}{r}14 \\
3 \\
\end{array}$ & $\begin{array}{r}19 \\
5 \\
\end{array}$ & $\begin{array}{r}33 \\
6 \\
\end{array}$ & $\begin{array}{l}5 \\
3 \\
\end{array}$ & $\begin{array}{r}10 \\
1 \\
\end{array}$ & $\begin{array}{r}114 \\
25 \\
\end{array}$ \\
\hline $\begin{array}{c}\text { (b) Moder- } \\
\text { ate } \quad \cdots \\
\text { Severe } \quad \cdots\end{array}$ & $\begin{array}{r}65 \\
4 \\
\end{array}$ & - & 1 & $\begin{array}{r}23 \\
2 \\
\end{array}$ & $\begin{array}{l}1 \\
1\end{array}$ & - & - & - & - & $\begin{array}{l}8 \\
1 \\
\end{array}$ & $\begin{array}{r}20 \\
3 \\
\end{array}$ & $\begin{array}{l}8 \\
2 \\
\end{array}$ & $\begin{array}{l}9 \\
2 \\
\end{array}$ & $\begin{array}{r}93 \\
7 \\
\end{array}$ \\
\hline $\begin{array}{l}\text { 4. Ch. (a) } \\
\text { Mild }\end{array}$ & 93 & 14 & 2 & 6 & - & - & 50 & 16 & 10 & 14 & 19 & 8 & 3 & 115 \\
\hline (b) Mild & 82 & 7 & 1 & 8 & 2 & - & - & - & - & 16 & 30 & 6 & 5 & 100 \\
\hline Totals $\quad \ldots$ & 335 & 51 & 7 & 56 & 5 & - & - & - & - & 63 & 111 & 32 & 30 & 454 \\
\hline Percentages & $73 \cdot 5$ & $11 \cdot 2$ & $1 \cdot 5$ & $12 \cdot 3$ & $1 \cdot 1$ & - & - & - & - & $13 \cdot 8$ & $24 \cdot 4$ & $7 \cdot 0$ & $6 \cdot 6$ & - \\
\hline
\end{tabular}

TABLE 7

\section{B. CHOREA-ANALYSIS OF CASES ADMITTED WITH HEART INVOLVEMENT}

B. ChOREA

MODERATE

Lesions on admis-

sion, which re- $<$

mained unaltered
except in (1)

Lesions which

in hospital

M.R. $\rightarrow$ M.S

(2) M.B. $\rightarrow$ A.R

(3) M.R. $\rightarrow$ M.S. $\rightarrow$ A.R

(4) M.R. (becoming well established)

\begin{tabular}{|l|l|l} 
Mitral systolic which cleared & .. & 21
\end{tabular}

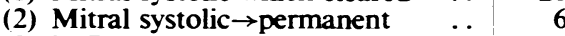

\begin{tabular}{llll|l|l} 
(3) M.R. & M & . . & . &.. & 21
\end{tabular}

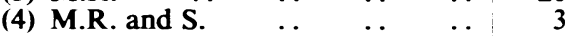

(5) M.R. and S., A.R. and S.
Groups 2 and 3

progressed while

\begin{tabular}{l|l|l|l|l|r}
$\mathbf{B}$ & $\mathbf{B}$ & $\mathbf{B}$ & $\mathbf{B}$ & & Per- \\
$\mathbf{2}$ & $\mathbf{2}$ & $\mathbf{3}$ & $\mathbf{3}$ & Totals & centag \\
(a) & (b) & (a) & (b) & & \\
\hline
\end{tabular}

Per-

\begin{tabular}{|r|r|r|r|r|}
\hline 14 & 18 & 11 & 64 & $27 \cdot 1$ \\
4 & 5 & 4 & 19 & $8 \cdot 0$ \\
26 & 14 & 5 & 66 & $27 \cdot 9$ \\
1 & 3 & 3 & 10 & $4 \cdot 2$ \\
\hline
\end{tabular}

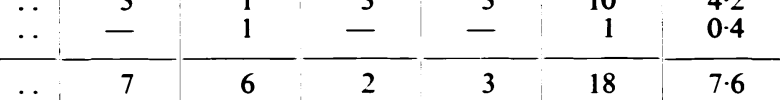

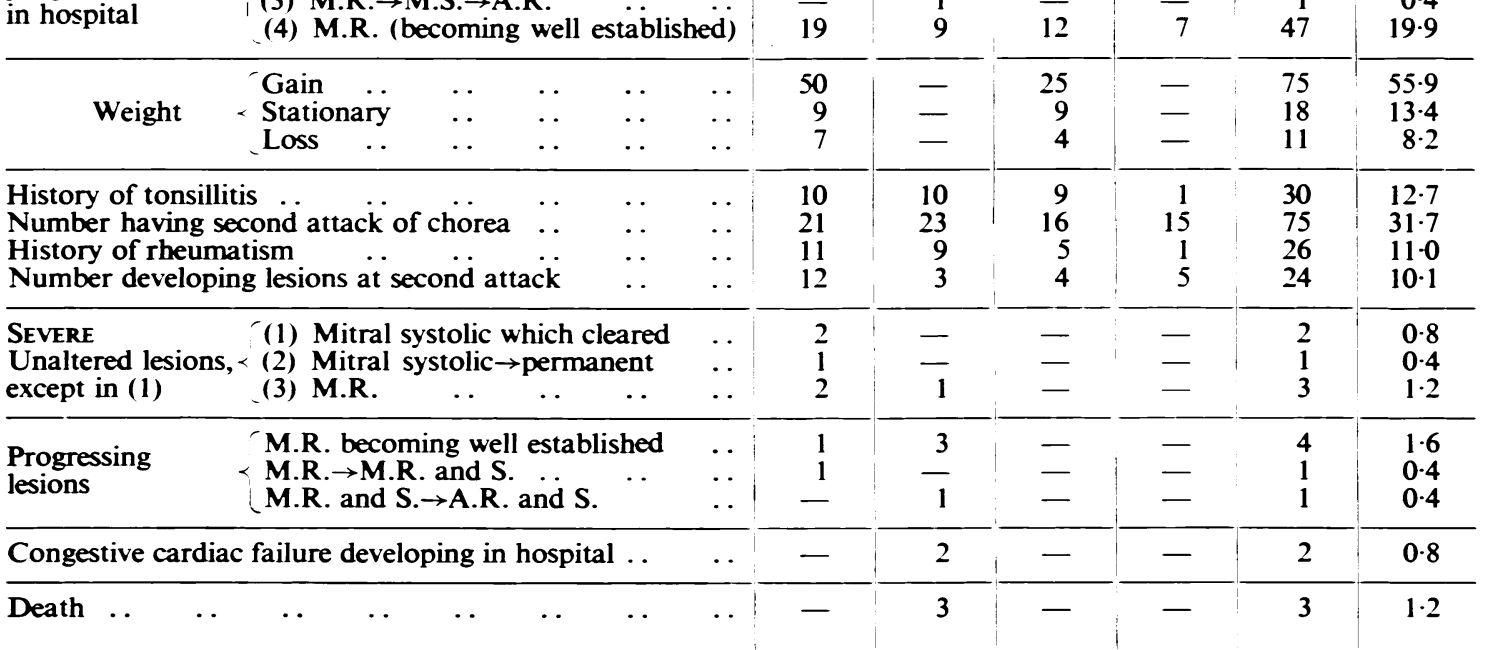


In addition to the foregoing detailed tables, it has been possible to obtain the following information:

Relapse rate. During the period under review, i.e. 1936, 1937, 1938, cases re-admitted have not been included twice, but note of their re-admission taken. From these figures the relapse rate can be calculated approximately:

Rheumatism. 66 , of whom 7 died at subsequent admission.

Therefore relapse rate $=7 \cdot 0$ per cent.

ChOREA. 75.

Therefore relapse rate $=10 \cdot 7$ per cent.

Prognosis. Of the 1632 cases, 49 were recommended to attend schools for physically defective children. This figure is probably somewhat smaller than it should have been, as, owing to lack of accommodation, such recommendations were reduced to a minimum. 134 children were referred to the School Medical Officer for further observation:

i.e. $1389(85 \cdot 1$ per cent.) may be said to be in good health

183 (11.2 per cent.) may be said to be in poor health

60 ( 3.6 per cent.) have died.

Clinical type. Of the 942 cases of rheumatism 245 (26.3 per cent.) were of the A.A.Rh. Group and 694 (73.6 per cent.) were of the V.P. Group, i.e. the syndrome of vague pains, ' growing pains,' lassitude, etc., is about three times as common as the acute articular type.

In the chorea group (group B) there were in all 690 cases, of whom-

45 ( 6.5 per cent.) were severe,

342 (49.5 per cent.) were moderate,

303 (43.9 per cent.) were mild.
Of the mild chorea, 16 out of 215 (7.4 per cent.) developed lesions de novo.

Of the severe chorea, 5 out of 32 (15.6 per cent.) developed lesions de novo.

\section{Incidence of heart lesions and attacks}

RheumatisM. Of the 942 cases, 684 were having their first attack and 258 were having their second or subsequent attack.

Of the 684 (first attack) cases, 180 (26.3 per cent.) developed lesions or progressed.

Of the 258 (second attack) cases, 83 (32.1 per cent.) developed lesions or progressed.

CHOREA. Of the 690 cases, 504 were having their first attack and 186 were having their second or subsequent attack.

Of the 504 (first attack) cases, 134 (26.5 per cent.) developed lesions or progressed.

Of the 186 (second attack) cases, 54 (29.0 per cent.) developed lesions or progressed.

Incidence of the various heart lesions or combinations of heart lesions-final result.

(a) Mitral regurgitation .. $\quad \ldots \quad \ldots 446$

(b) Mitral regurgitation and stenosis .. 208

(c) Mitral regurgitation and stenosis and aortic regurgitation ... . . .

(d) Mitral regurgitation and stenosis and aortic regurgitation and stenosis ..

(e) Mitral regurgitation and aortic regurgitation

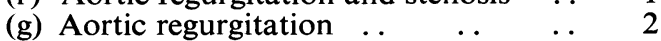

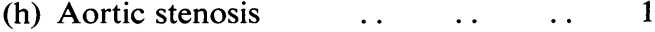

Removal from hospital. Of the 1632 cases, 119 (7.2 per cent.) were taken home on their parents' responsibility, one of them on two occasions.

Death rates

(a) General death rate-of 1632 cases, 60 (3.6 per cent.) died.

TABLE 8

SHOWING INCIDENCE OF HEART INVOLVEMENT

\begin{tabular}{|c|c|c|c|c|c|c|c|c|c|}
\hline & & & & $\begin{array}{l}\text { Rheuma- } \\
\text { tism }\end{array}$ & $\begin{array}{c}\text { Average } \\
\text { per annum }\end{array}$ & Chorea & $\begin{array}{c}\text { Average } \\
\text { per annum }\end{array}$ & Total & $\begin{array}{l}\text { Average } \\
\text { per annum }\end{array}$ \\
\hline $\begin{array}{l}\text { 'New Hearts' } \\
\text { Established ' } 1 \\
\text { Established ' } ~ \\
\text { Total .. } \\
\text { Percentage }\end{array}$ & 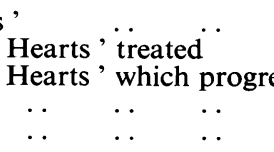 & $\begin{array}{l}\ldots \\
\ldots \\
\text { essed } \\
\ldots \\
\cdots\end{array}$ & $\begin{array}{l}\cdots \\
\cdots \\
\cdots \\
\cdots\end{array}$ & $\begin{array}{c}77 \\
248 \\
186 \\
511 \\
54 \cdot 2\end{array}$ & $\begin{array}{r}25 \\
82 \\
62 \\
170\end{array}$ & $\begin{array}{c}61 \\
80 \\
73 \\
214 \\
31 \cdot 0\end{array}$ & $\begin{array}{l}20 \\
28 \\
24 \\
71\end{array}$ & $\begin{array}{c}138 \\
328 \\
259 \\
725 \\
44 \cdot 4\end{array}$ & $\begin{array}{r}46 \\
109 \\
86 \\
241\end{array}$ \\
\hline $\begin{array}{l}\text { No lesion } \\
\text { Mitral systolic } \\
\text { Doubtful }\end{array}$ & $\begin{array}{ccc}\text { ic which } & \text { disappeared } \\
. & \ldots & .\end{array}$ & $\begin{array}{l}\cdots \\
\cdots \\
\cdots\end{array}$ & $\begin{array}{l}\cdots \\
\cdots \\
\cdots\end{array}$ & $\begin{array}{r}203 \\
195 \\
33\end{array}$ & $\begin{array}{l}67 \\
65 \\
11\end{array}$ & $\begin{array}{r}335 \\
115 \\
26\end{array}$ & $\begin{array}{r}111 \\
38 \\
8\end{array}$ & $\begin{array}{r}538 \\
310 \\
59\end{array}$ & $\begin{array}{r}179 \\
103 \\
19\end{array}$ \\
\hline
\end{tabular}

Incidence of heart lesions in clinical types

Rheumatism (Group A, 1 and 4 -presenting no lesion on admission).

Of the A.A.Rh. group, 34 out of $117(29.0 \mathrm{per}$ cent.) developed lesions de novo.

Of the V.P. group, 43 out of 240 (17.9 per cent.) developed lesions de novo.

CHOREA (Group B, 1 and 4-presenting no lesion on admission).

Of the moderate chorea, 40 out of 207 (19.3 per cent.) developed lesions de novo. (b) Rheumatism death rate-of 942 cases, 57 (6.0 per cent.) died.

(c) Chorea death rate-of 690 cases, $3(0.4$ per cent.) died.

(d) Rheumatic cases which possessed or developed ' hearts,' death rate-of the 511 cases, 57 (11.1 per cent.) died.

(e) Choreic cases which possessed or developed ' hearts,' death rate-of the 214 cases, 3 (1.4 per cent.) died. 


\section{Incidence of transient systolic murmur}

RHEUMATISM. Of the 585 cases with heart involvement on admission, 195 (33.3 per cent.) had a mitral systolic murmur which disappeared.

CHOREA. Of the 236 cases with heart involvement on admission, 115 (48.7 per cent.) had a mitral systolic murmur, which disappeared.

Total 821, 310 (37.7 per cent.).

TABLE 9

\section{INCIDENCE OF TONSILLITIS}

\begin{tabular}{|c|c|c|c|c|}
\hline \multirow[t]{2}{*}{ RHEUMATISM } & \multicolumn{2}{|c|}{$\begin{array}{l}\text { Without his- } \\
\text { tory of ton- } \\
\text { sillitis } \\
608 \text { cases }\end{array}$} & \multicolumn{2}{|c|}{$\begin{array}{l}\text { With history } \\
\text { of tonsillitis } \\
301 \text { cases }\end{array}$} \\
\hline & $\begin{array}{l}\text { Num- } \\
\text { ber }\end{array}$ & $\begin{array}{l}\text { Per- } \\
\text { cent- } \\
\text { age }\end{array}$ & $\begin{array}{c}\text { Num- } \\
\text { ber }\end{array}$ & $\begin{array}{l}\text { Per- } \\
\text { cent- } \\
\text { age }\end{array}$ \\
\hline \multirow{2}{*}{$\begin{array}{l}\text { 1. Lesions which developed } \\
\text { or progressed } \\
\text { 2. Lesions on admission } \\
\text { which did not progress } \\
\text { 3. No lesion .. .. }\end{array}$} & 182 & 29.9 & 81 & $27 \cdot 2$ \\
\hline & $\begin{array}{l}208 \\
218\end{array}$ & $\begin{array}{l}34 \cdot 2 \\
35 \cdot 8\end{array}$ & $\begin{array}{r}40 \\
180\end{array}$ & $\begin{array}{l}13 \cdot 2 \\
59 \cdot 0\end{array}$ \\
\hline \multirow[b]{2}{*}{ CHOREA } & \multicolumn{2}{|c|}{571 cases } & \multicolumn{2}{|c|}{93 cases } \\
\hline & $\begin{array}{l}\text { Num- } \\
\text { ber }\end{array}$ & $\begin{array}{l}\text { Per- } \\
\text { cent- } \\
\text { age }\end{array}$ & $\begin{array}{c}\text { Num- } \\
\text { ber }\end{array}$ & $\begin{array}{l}\text { Per- } \\
\text { cent- } \\
\text { age }\end{array}$ \\
\hline $\begin{array}{l}\text { 1. Lesions which developed } \\
\text { or progressed } \\
2 \text { Lesions on admission }\end{array}$ & 124 & $21 \cdot 7$ & 10 & $10 \cdot 7$ \\
\hline $\begin{array}{l}\text { which did not progress } \\
\text { 3. No lesion }\end{array}$ & $\begin{array}{r}68 \\
379\end{array}$ & $\begin{array}{l}11 \cdot 9 \\
66 \cdot 3\end{array}$ & $\begin{array}{l}12 \\
71\end{array}$ & $\begin{array}{l}12 \cdot 9 \\
76 \cdot 3\end{array}$ \\
\hline
\end{tabular}

Pericarditis. One case occurred in the chorea group, which died.

In the rheumatism group there were 64 , of whom 25 ( 39.0 per cent.) died.

In the A.A.Rh. group there was 1 case which recovered.

Of 694 cases, 63 ( 9.0 per cent.) had nodules.

The sex distribution was approximately equal.

Of the 942 cases of rheumatism, 79 (8.2 per cent.) showed nodules.

Of the 79 cases with nodules, 19 (24.0 per cent.) died.

Of the 19 deaths, $12(63 \cdot 1$ per cent.) occurred in association with pericarditis.

Erythema marginatum. Of the 942 cases of rheumatism, 17 (1.8 per cent.) showed erythema marginatum, and of these only one died in congestive cardiac failure.

Incidence of affection in various joints in A.A.Rh.

$$
\begin{array}{lllllr}
\text { Ankles } & . & . & . & . & 210 \\
\text { Knees .. } & . & . & . & . & 117 \\
\text { Wrists .. } & . & . & . & . & 55 \\
\text { Hips .. } & . & . & . & . & 13 \\
\text { Elbows. } & . & . & . & . & 12 \\
\text { Fingers } & . & . & . & . & 8 \\
\text { Shoulders } & . & . & . & . & 3
\end{array}
$$

Occasionally lesions of the hip-joint and more rarely the knee-joint, when such joint was the only one affected at the time of examination, gave rise to difficulty in diagnosis between rheumatic infection and osteomvelitis, or septic arthritis, especially when the child had a high temperature and looked ill. A useful diagnostic sign was observed in the presence or absence of delirium. In the presence of delirium the lesion was invariably found to be either osteomyelitis or septic arthritis. Delirium has not been observed in cases of rheumatic infection.

Temperature and pulse. For this purpose the group of acute articular rheumatisms admitted without evidence of heart involvement have been analysed ( 117 cases; unit of time $=3$ days).

\section{Discussion}

\begin{tabular}{|c|c|c|c|c|c|c|c|c|c|c|c|c|c|c|c|c|}
\hline \multirow{2}{*}{\multicolumn{5}{|c|}{ Type of case }} & \multicolumn{5}{|c|}{ Temperature in units } & \multicolumn{7}{|c|}{ Pulse in units } \\
\hline & & & & & 1 & 2 & 3 & 4 & $5-$ & 1 & 2 & 3 & 4 & 5 & 6 & $7-$ \\
\hline Heart lesion which & develope & progressed & . & . & 12 & 13 & 4 & 1 & 3 & 0 & 12 & 16 & 2 & 2 & 1 & 1 \\
\hline $\begin{array}{c}\text { Cases developing a } \\
\text { appeared }\end{array}$ & mitral & $\begin{array}{c}\text { tolic murmur } \\
\ldots\end{array}$ & $\begin{array}{l}\text { whic } \\
\text {. }\end{array}$ & $\begin{array}{l}\text { dis- } \\
\ldots\end{array}$ & 16 & 7 & 1 & 0 & 0 & 3 & 10 & 14 & 1 & 0 & 0 & 0 \\
\hline No lesion $\ldots$ & $\cdots$ & . & $\cdots$ & $\bar{\cdots}$ & 28 & 15 & 3 & 0 & 0 & 5 & 22 & 16 & 2 & 0 & $\mathbf{0}$ & 0 \\
\hline
\end{tabular}

It is not proposed to deal with the extensive literature on this subject in any detail and reference will only be made to a few of the larger surveys. Some justification for the classification employed may be found in a statement by Findlay (1931), who,

TABLE 10

In the V.P. group there were 63 cases, of whom 25 died.

Congestive cardiac failure. There was a total of 43 cases, of whom $28(65 \cdot 1$ per cent.) died.

\section{Nodules}

Rheumatism. (Group A, 1 and 2-A.A. Rh.). Of 248 cases, $16(6.4$ per cent.) had nodules. (Group A, 3 and 4 V.P.) dealing with the assessment of the incidence of rheumatic infection says, 'It would also be advisable that chorea and arthritis, with and without carditis, be also specifically stated, as it is only in this way that the personal bias of the individual medical man can be eliminated, and definite information regarding the relative frequency of the mild and grave types of the disease elicited.' Table 1 demonstrates 
the well-known fact that the classical picture of acute articular rheumatism with swelling, redness and pain in joints is considerably less frequent than the syndrome of vague pains, 'growing pains,' lassitude, etc. The insidious nature of the infection is one of the most potent factors in rendering control of this disease extremely difficult. This has been the experience elsewhere, e.g. Ministry of Health Report, No. 44 (1927), in which it is stated that arthritic phenomena are not so common as vague symptoms. Considerably fewer cases of chorea were admitted with signs of heart involvement than was the case in rheumatism. The table also shows that, while the physician in charge of the after-care clinic considered that the clinic was at times busy, in fact, 44.8 per cent. did not attend at all, and table 2 shows that the record of those who did attend was not all that could be desired. Table 3 demonstrates once again the well-known higher incidence of chorea in girls, the ratio being males: females as $1: 2 \cdot 3$. Findlay's figure is $1: 2 \cdot 8$. He also finds arthritic phenomena commoner in girls, the ratio being $1: 1 \cdot 1$ and the ratio in the present series is almost identical-1:1.09. The graph (fig. 1) indicates the age distribution. The terminal fall between the ages of 14 to 16 years may be to some extent artificial as cases over 16 were not admitted. Still, the graph is similar to that illustrating Schlesinger's Milroy Lectures (1938). Tables 4, 5, 6 and 7 show that valvular lesions occur in the following order of frequency-mitral regurgitation, mitral regurgitation and stenosis, and aortic disease. Without going into detail this is in accord with other writings, e.g. Findlay: mitral regurgitation 473, mitral stenosis 216 , aortic regurgitation 59; and Schlesinger: mitral regurgitation 368, mitral stenosis 272, mitral and aortic disease 85 . Aortic stenosis alone is extremely rare and was only noted in one case. Schlesinger (1938) mentions only two which were in combination with mitral disease.

The relapse rate ( 8.8 per cent.) has been calculated approximately, as nothing is known of those who probably relapsed, but did not report at the hospital. For this reason the present figure is lower than other recorded figures. Schlesinger found 35 per cent. in his series, whilst other authors put it as high as $\mathbf{6 0}$ to 70 per cent. Forrest Smith (Ministry of Health Report, 1927), who rightly calls attention to the difficulty in deciding what is and what is not a relapse in the course of such a prolonged disease, found a relapse rate of 85.3 per cent. In another series she mentions that 77 per cent. of cases were treated as out-patients from their homes, while all the cases in the present series had adequate hospital treatment. It is possible that herein lies one reason for the great discrepancy between her relapse rate and that of the present series.

The percentage of the cases who are alive and well (85.1 per cent.), is similar to the findings of Schlesinger ( 81.7 per cent.), but there are discrepancies between his figures of those in poor health and those who are dead, and the figures of the present series.
These discrepancies will be dealt with later. $44 \cdot 4$ per cent. were found to develop heart lesions or to possess heart lesions. An average of 46 ' new hearts' and an average of 86 heart lesions which progressed, occurred each year. These figures are rather lower than those found by Findlay, who states that heart disease occurs in 75 per cent. of rheumatic arthritis and in $\mathbf{5 0}$ per cent. of chorea. On the other hand they are worse than Forrest Smith's figures. In her first series 21.9 per cent. had heart lesions and in her second series 29.8 per cent. In the rheumatic group a materially greater percentage of heart lesions developed in the group of acute articular rheumatism than in the group presenting the 'vague pains syndrome.' In the moderate and severe choreas there is no great difference. There is a greater incidence of heart disease in rheumatism than in chorea, which is in agreement with Findlay's findings. $26 \cdot 3$ per cent. developed lesions or progressed during their first attack, while $32 \cdot 1$ per cent. did so during their second or subsequent attack. The difference is not so striking in the case of chorea. In general this is in accord with Findlay's findings. The general death rates are remarkably low, i.e. in rheumatism, only 6 per cent., which is lower than Schlesinger's figure of $12 \cdot 3$ per cent. It must be remembered that his series is composed of cases of rheumatic heart disease. In the present series, in those cases of rheumatism which developed or possessed heart lesions, the death rate is $11 \cdot 1$ per cent., which is similar to Schlesinger's figure.

It is suggested that, as all cases of rheumatic infection are included in the present series, the death rate of 6 per cent. gives a more accurate idea of the death rate in this infection. In 37.7 per cent. of the cases a mitral systolic murmur disappeared. Similar figures have been found by various authors. Schlesinger quotes 30 per cent. by Carey Coombs and 37 per cent. by Morse. Findlay had 54 such cases, but found that in a proportion this murmur returned after a period of years. He suggests myocarditis as the cause of such murmurs. Forrest Smith had 21.3 per cent. of such cases in her first series and 23.5 per cent. in her second.

Most writers seem to agree that tonsillitis plays a part in the etiology of rheumatic infection, and many figures are produced to show that there is a greater incidence of tonsillitis and tonsillar infection in rheumatic subjects than in non-rheumatic subjects. As the prognosis in rheumatic infection depends upon whether the heart is affected or not, it is strange that the authors consulted have not tried to establish the relationship between tonsillitis and the occurrence of heart involvement. An attempt has been made to do this in the present series with a somewhat unexpected result. Table 9 shows that in those with a history of tonsillitis 27.2 per cent. had lesions which developed or progressed, while in those with no such history the percentage was 29.9 per cent. In chorea tonsillitis appears to exert no influence on the incidence of heart disease. Findlay found a history of tonsillitis 
in only 4 per cent. of his cases and as he says, in the Medical Research Council's Report, No. 114 (1927), a history of recurrent sore throat was obtained in 18 per cent. of rheumatic cases and in 16 per cent. of non-rheumatic cases or control cases. In pericarditis the death rate of $39-0$ per cent. compares favourably with other figures, e.g. Schlesinger 50 per cent. and Findlay 63.4 per cent. The presence of nodules is generally regarded as of bad omen, and this is confirmed in the present series. Their incidence is roughly similar to that discovered by Schlesinger ( 9 per cent.) and Findlay (10 per cent.). Schlesinger's death rate (40 per cent.) is rather higher than in the present series and a high percentage was found in association with pericarditis, both in the present series and by Findlay. Erythema marginatum was found in only a small proportion of cases. The incidence of affection of the various joints is parallel with Findlay's experience. He has found affection of the right hip-joint simulating appendicitis and leading to operation. The present writer has not experienced this complication. Temperature and pulse rates are not always helpful, although a greater number of cases with prolonged pyrexia and elevation of pulse rate is found in the cases which developed heart lesions. Pyrexia may be absent in active cases.

\section{Comment}

At the present time, when planning for the future bulks so largely on the medical horizon, the present series serves to re-emphasize the great importance of rheumatic infection in childhood. This is especially important when it is considered that diseases of the heart and circulation have the highest death rate and that 50 to 60 per cent. of these are due to rheumatic infection, a large proportion of which is acquired in childhood. An average of 241 cases per annum of rheumatic heart disease in one hospital is a startlingly large number. It has been estimated that the number of beds necessary for the adequate treatment of rheumatic infection in childhood should be computed on the basis of 1.7 beds per 1000 elementary school children. In the City of Liverpool the number of elemenary school children, taking 1937 as an average year, was 132,884 , so that at least 225 beds should be available. Probably this is an inadequate figure. An attempt was made in Alder Hey Children's Hospital to treat all cases of rheumatic infection or suspected rheumatic infection, whether showing evidence of cardiac involvement or not. Findlay says, 'It cannot be too strongly stated that it is to the milder example of the disease and especially before the heart has been involved, that particular attention should be paid, since the greatest achievement of our treatment and the greatest blessing to the patient is to keep the heart from becoming affected.' In the opinion of the writer it is impossible, in the course of one or even two examinations as an out-patient, to determine whether the rheumatic process is active or not. It is necessary to have the child under close and skilled observation in bed in hospital for a period of a few weeks. If this ideal situation is to develop then perhaps an even greater number of beds should in the future be made available for this purpose.

It is generally agreed that rheumatic clinics or after-care clinics are extremely useful; but when the child is referred to the school medical officer, or to a school for physically defective children, he passes out of the care of the physician who knows the child from the inception of his illness. Whilst it is not intended to criticize adversely the admirable work of the school medical service, it is felt that arrangements should be made whereby the hospital physicians supervise the progress of the rheumatic child while at the school for physically defective children. In other words, there should be continuity of supervision. The ideal is the residertial school such as is in operaton in Birmingham. In the writer's opinion such schools should be medically supervised by the physician of the hospital and preferably should be in adjacent premises if the parent hospital is suitably situated. Education in such schools should to a greater extent be designed to fit the cardiac cripple for some useful employment. The writer has frequently recommended a sedentary occupation, only to find that the child's educational attainments automatically debar him from such employment. It was disappointing to find that only 50 per cent. attended the after-care clinic and that those who did attend, attended so badly. The remedy lies in teaching parents the dangers of rheumatic infection, and eradication of the common idea that the function of a clinic is to supply a bottle of medicine.

On the whole the prognosis is not unfavourable and the writer is convinced that it could be improved by early and continuous supervision, if necessary until adolescence is reached. There is little justification for the view recently expressed by Parsons-Smith (1942) that 'in children carditis in some form is practically an inevitable development.' The problem is an immense one and in planning the medical service of the future it merits detailed consideration.

Thanks are due to Dr. W. E. Crosbie, Medical Superintendent, Alder Hey Children's Hospital, Liverpool, for permission to publish this paper; and to Dr. N. B. Capon for his advice and criticism.

\section{REFERENCES}

Annual Report of the Chief Medical Officer of the Board of Education (1935), p. 102.

Findlay, L. (1931). The rheumatic infection in childhood. London.

Medical Research Council's Report (1927). London, No. 114, p. 35.

Ministry of Health Report (1927). London, No. 44, p. 50.

Parsons-Smith, B. (1942). Post-Grad. med. J., 197, 10. Schlesinger, B. (1938). Lancet, 1, 593 and 649. 